\title{
The 16S rRNA Analysis and Enzyme Screening of Bacillus from Rhizosphere Soil of Lombok Island
}

\section{(Analisis 16S rRNA dan Skrening Enzim Bacillus dari Tanah Rhizosfer Pulau Lombok)}

\author{
Tri Ratna Sulistiyani*, Mia Kusmiati, Gita Azizah Putri
}

(Diterima Januari 2021/Disetujui April 2021)

\begin{abstract}
Bacillus are commonly found in nature, especially in soil and food. It has the ability to produce bioactive compounds as well as the enzyme. This study was aimed to isolate, identify, and screen their enzyme activities. Four soil samples from Mandalika, Lombok Island, West Nusa Tenggara (NTB), were used for isolation. Bacillus was isolated using the heat-shock method and characterized through Gram staining, endospore staining, and morphological phenotype. Bacillus identification was conducted based on 16S rRNA gene sequence. The hydrolytic enzyme activities were checked qualitatively using selective media, and the enzyme tested including amylase, galactosidase, lipase, protease, and cellulase. As many as twenty-two bacteria isolates were obtained from four soil samples and represented 15 distinct species. The member of bacteria genera successfully identified, consisted of Bacillus sp., Brevibacillus sp., and Fictibacillus sp. Bacillus sp. was the most isolated. Some of the isolated bacteria have the ability to produce lipase, protease, and cellulase that potential to be used in biotechnology processes.
\end{abstract}

Keywords: Bacillus, hydrolytic enzymes, identification, screening

\section{ABSTRAK}

Bacillus secara umum ditemukan di alam, terutama di tanah dan makanan. Bakteri dalam kelompok tersebut memiliki kemampuan untuk menghasilkan senyawa bioaktif seperti enzim. Penelitian ini bertujuan untuk mengisolasi, mengidentifikasi, dan menskrening aktivitas enzim yang dihasilkan oleh bakteri dari kelompok Bacillus. Empat sampel tanah dari Pulau Mandalika, Nusa Tenggara Barat (NTB) digunakan dalam penelitian ini. Bacillus diisolasi menggunakan metode heat-shock dan dikarakterisasi menggunakan pendekatan pewarnaan Gram, pewarnaan endospore, dan morfologi fenotipe. Identifikasi dilakukan berdasarkan urutan gen 16S rRNA. Aktivitas enzim hidrolisis dicek secara kualitatif menggunakan media selektif, dan enzim yang diuji antara lain amilase, galaktosidase, lipase, protease, dan selulase. Sebanyak dua puluh dua isolat diperoleh dari empat sampel tanah dan mewakili 15 spesies berbeda. Beberapa genus bakteri yang berhasil diisolasi antara lain Bacillus sp., Brevibacillus sp., dan Fictibacillus sp. Bacillus sp. terisolasi paling banyak dibanding dua genus lainnya. Beberapa bakteri terisolasi memiliki kemampuan untuk menghasilkan enzim lipase, protease, dan selulase yang berpotensi untuk digunakan dalam proses bioteknologi.

Kata kunci: Bacillus, enzim hidrolisis, identifikasi, skrening

\section{INTRODUCTION}

As part of life, microbes directly contribute to the life cycle and sustainability of materials used in the environment, food, agriculture, health, and industry. The contributions of microbes depend on their diversities. Bacillus are widely applied in the food, environmental, agricultural, and industrial processes. These bacteria spread in nature and are commonly found in soil, clay, rock, dust, aquatic environment, food, the digestive tract of insects and aquatic animals (Schultz et al. 2017). Therefore, these bacteria could

Research Center for Biology-Indonesian Institute of Sciences (LIPI), Jl. Raya Jakarta Bogor Km. 46 Cibinong, 16911

* Correspondence author:

Email: trilisty01@gmail.com be isolated in almost all types of samples. Taxonomically, Bacillus belongs to Gram-positive bacteria, phylum Firmicutes, Bacillales orders, with characteristics: aerobic, rod-shaped, straight, flat, rhizoid, and white chalk. The records in January 2019, the Bacillus genera, consisted of 379 species, including its synonym (Parte \& Road 2014).

Nowadays, Bacillus genera getting more attention due to their capabilities in secreting bioactive compounds, such as enzymes, antimicrobials, and other potential commercial compounds (Caulier et al. 2019). The other studies by Shanthi and Roymon (2018) and Powthong and Suntornthiticharoen (2017) reported that Bacillus sp. have the abilities to produce xylanase, chitosanase, amylase, cellulase, caseinase, esterase, and lipase. The well-known species of Bacillus are Bacillus subtilis, Bacillus licheniformis, 
Bacillus amiloliquefaciens (van Dijil \& Hecker 2013), and Bacillus thuringiensis (Shrestha et al. 2015).

Microbial enzymes are more interesting compared to plants and animals due to their stability, availability, and cost-effectiveness. These conditions made microbial enzymes were explored more and applied in many industrial sectors that highly dependent on enzymes. Fungi, bacteria, and actinomycetes mostly produce enzymes, and the most commercial one is fungi. However, bacteria are also considered enzyme producers because they are fast-growing, stable in the extreme conditions, and sometimes have multiple enzymes. The abilities of bacteria to produce multienzymes will increase the benefits when used as food additives (Pereyra et al. 2020). Approximately $50 \%$ of total enzyme market are produced by Bacillus. This mainly due to these bacteria have a wide distribution, easy to cultivate, safety, and susceptibility to genetic transformations. In addition, protease from Bacillus is stable in wide range of temperature and $\mathrm{pH}$, that suitable for industrial application (Danilova \& Sharipova 2020). About more than $65 \%$ of industrial enzymes on the market are proteases (Annamalai et al. 2014). About $40 \%$ of the total production of protease enzyme are obtained from microbes. Besides protease, lipase also a vital enzyme in the industrial field that is applied in detergent formulations and methyl ester production.

The increasing demand for enzymes leads to doing more explorations. In this work, we investigated the diversity of Bacillus from soil sample and screened the enzymes activities. Through enzyme screening, we could obtain information about its ability to produce enzymes that economically prospective in the industrial field.

\section{MATERIALS AND METHODS}

\section{Samples Source}

The rhizosphere soils were collected from various locations on Mandalika, Lombok Island, in April 2019. Samples were taken from a depth of $5 \mathrm{~cm}$ and collected from the rhizosphere of Peltophorum pterocarpum (SSLO1), Cocos nucifera (SSLO2), Arenga pinnata (SSLO3), and Theobroma cacao (SSLO5).

\section{Isolation and Preservation of Bacillus}

For Bacillus isolation, a combination of heat-shock and serial dilution was employed. A total of one g soil sample was diluted using $9 \mathrm{~mL}$ of sterile distilled water, mixed properly, and heated using a water bath at $80^{\circ} \mathrm{C}$ for $10 \mathrm{~min}$. The sample suspension was cooled for 2 min and followed with serial dilutions making the concentration to $10^{-4}$. As much as $100 \mu \mathrm{L}$ of level $10^{-2}$ to $10^{-4}$ dilutions were spread aseptically on the Nutrient Agar (NA) media and incubated at $30^{\circ} \mathrm{C}$ for $24-48$ hours. The colony growth was observed and counted. The colonies showed different morphologies were taken and purified based on the quadrant method until a single colony was obtained. The selected isolates were characterized on the basis of Gram-staining, endospore staining, and morphological phenotype i.e., form, color, margin, and elevation. The purified isolates were stored in a $10 \%$ glycerol solution and keep in a freezer at $-80^{\circ} \mathrm{C}$.

\section{Identification Based on The 16S rRNA Gene Molecular Approach}

DNA extraction was conducted based on the method described by Packeiser et al. (2013). A single colony of bacterial cells was taken using sterile toothpicks and suspended in $50 \mu \mathrm{L}$ of free nuclease water. The cell lysis was done by incubation at $98^{\circ} \mathrm{C}$ for $5 \mathrm{~min}$. The supernatant containing DNA and cell debris was separated using spin down. The supernatant called DNA extract was taken and stored in the new tube for PCR amplification.

PCR amplification was performed using a pair of universal primers for eubacteria, namely primers $27 \mathrm{~F}$ (5'-AGAGTTTGATCCTGGCTCAG-3') and 1492R (5'GGTTACCTTGTTACGACTT-3' (Lane 1991). 16S rDNA amplification was made in $25 \mu \mathrm{L}$ total volume. The composition involved GoTaq Green Master Mix, primers $27 \mathrm{~F}$ and $1492 \mathrm{R}$, dimethyl sulfoxide (DMSO), DNA template, and Ultrapure water. The PCR condition was set as: initial denaturation at $95^{\circ} \mathrm{C}$ for $90 \mathrm{sec}$, followed by 30 cycles of denaturation at $95^{\circ} \mathrm{C}$ for 30 sec; annealing at $50^{\circ} \mathrm{C}$, for $30 \mathrm{sec}$; elongation at $72^{\circ} \mathrm{C}$, for $90 \mathrm{sec}$ and a final extension at $72^{\circ} \mathrm{C}$ for $5 \mathrm{~min}$, and finally at $4^{\circ} \mathrm{C}$ for 20 minutes. The amplified DNA was electrophoresed on $1 \%$ agarose gel, stained with ethidium bromide $\left(5 \mathrm{mg} \mathrm{mL}^{-1}\right)$, and visualized using a UV transilluminator.

\section{DNA Sequencing and Phylogenetic Analysis}

The amplified DNA sequencing was performed using an automated DNA sequencer (ABI PRISM 3130 Genetic Analyzer) (Applied Biosystems) with a pair of primers $27 \mathrm{~F}$ and $1492 \mathrm{R}$. The sequencing data were processed using the Chromas Pro program. The closest identity was searched through the EzTaxon website (http://www.ezbiocloud.net/;) (Yoon et al. 2017), and reference sequences were obtained from GeneBank/DDBJ/EMBL. The phylogenetic tree was constructed using the Neighbor-Joining method (NJT), which was implemented in the MEGA 6.0 program (Tamura et al. 2013). The T92+G+l (Tamura3parameter and Gamma distributed) model was chosen as the best model for phylogenetic tree analysis and 1.000 bootstrap replication.

\section{Screening of Enzymes-Producing Bacillus Strains}

Bacteria isolates were streaked on NA media and incubated at $37^{\circ} \mathrm{C}$ for $24 \mathrm{~h}$. In the $24^{\text {th }}$ hour, the isolate was used in the screening of amylase, $\beta$-glucosidase, lipase, protease, and cellulase. The enzyme activity assay of bacterial isolates was performed by growing the isolates on selective media.

Screening of amylase activity was carried out using Modified Basal Medium (MM), consisting of $1 \mathrm{~g}$ glucose, $2,5 \mathrm{~g}$ yeast extract, $16 \mathrm{~g}$ bacto agar, $1.000 \mathrm{~mL}$ distilled water with the addition of $1 \%$ soluble starch 
(Mazzucotelli et al. 2013). Bacteria isolates were spotted on selective amylase media and incubated for $24 \mathrm{~h}$. After that time, the plate was flooded with Lugol solution as an indicator of starch and allowed to stand for $15 \mathrm{~min}$. The clear zone formed around the bacteria colony revealed a positive amylase activity. The clear area and index diameter were measured (Mazzucotelli et al. 2013).

The $\beta$-galactosidase activity was evaluated using a medium with a composition of $1,8 \mathrm{~g} \mathrm{~K}_{2} \mathrm{HPO}_{4}, 4,0 \mathrm{~g}$ $\mathrm{NH}_{4} \mathrm{Cl}, 0,2 \mathrm{~g} \mathrm{MgSO} 4.7 \mathrm{H}_{2} \mathrm{O}, 0,1 \mathrm{~g} \mathrm{NaCl}, 0,01 \mathrm{~g}$ $\mathrm{FeSO}_{4} .2 \mathrm{H}_{2} \mathrm{O}, 16 \mathrm{~g}$ bacto agar, $1.000 \mathrm{~mL}$ distilled water, with the addition of $1 \%$ lactose (Castro et al. 2014). The bacteria were spotted on the plate media and followed by incubation at $37^{\circ} \mathrm{C}$ for $24 \mathrm{~h}$. At the $24^{\text {th }} \mathrm{h}$, the plate was flooded with Lugol solution and allowed to stand for $15 \mathrm{~min}$. A positive reaction was indicated by forming clear zones around the colony. The diameter formed was measured, and the index calculated. Measurement of the value of enzyme-activity index was carried out by the following formula: (diameter of the clear zonediameter of the colony) / diameter of the colony (Castro et al. 2014).

The evaluation of protease activity was carried out using MM media with the addition of $6.2 \mathrm{~g} / \mathrm{L}$ skim milk (Mazzucotelli et al. 2013). Bacteria isolate was spotted on the selective media surface and incubated at $37^{\circ} \mathrm{C}$ for 24 hours. The clear zones formed around the colonies on protease-selective media indicated protease activity. The diameter of clear zones and indexes were measured.

The lipase activity was detected using a medium containing $10 \mathrm{~g}$ peptone, $0,1 \mathrm{~g} \mathrm{CaCl}_{2} .2 \mathrm{H}_{2} \mathrm{O}, 5 \mathrm{~g} \mathrm{NaCl}$, $10 \mathrm{~mL}$ Tween $80,16 \mathrm{~g}$ bacto agar, and $1.000 \mathrm{~mL}$ distilled water. The formation of white precipitation around the colonies indicates lipase activity. White precipitation is the deposition of crystals from calcium salts formed by fatty acids from microorganisms lipase (Mazzucotelli et al. 2013). The diameter size is $7 \mathrm{~mm}$ or more, which indicates positive lipase activity. The formula index value was calculated: (diameter of white precipitation-diameter of the colony) / diameter of the colony (Mazzucotelli et al. 2013).

Cellulase activity was checked using MM media with the addition of $1 \%$ carboxymethyl-cellulose (CMC) as a substrate. After incubated for 48 hours, the media was flooded with $0,1 \%$ Congo red solution, allowed to stand for 15-20 min, and rinsed with $1 \mathrm{M} \mathrm{NaCl}$ solution for 15-20 min. Cellulase activity was shown by forming a yellow color around the colonies. The yellow color diameter was measured and the index was calculated (Mazzucotelli et al. 2013).

\section{RESULTS AND DISCUSSION}

\section{The Abundance of Bacillus in the Sample}

Bacillus sp. is one of the bacterial groups that are most widely distributed in the natural environment, commonly found in soil, air, and food (Schultz et al.
2017), and able to survive in extreme environments, such as thermal treatment. The endospores forming is a specific character of Bacillus and makes it resistant to heat, desiccation, and UV light. Heat-shock treatment at $80^{\circ} \mathrm{C}$ for 10 minutes is an isolation method of Bacillus or spore-forming bacteria. The heating is effective in eliminating mesophilic nonspore-forming bacteria or other vegetative cells in the sample. The data presented in Figure 1 revealed that each sample had different riches of Bacillus. The highest abundance obtained from SSLO3 was collected from rhizosphere soil of $A$. pinnata, followed by SSLO2 from the rhizosphere soil of $C$. nucifera, SSLO1 from the rhizosphere of $P$. pterocarpum, and the last was SSLO5 from the rhizosphere of $T$. cacao. The result revealed that the abundances of microbes in the rhizosphere were influenced by the plant species and sampling locations.

The rhizosphere is one of the habitats that are rich in nutritional sources. Some studies stated that the riches of microorganisms are different up to several times between the rhizosphere and open soil (York et al. 2016; Bulgarelli et al. 2015; Schlaeppi et al. 2014). Further studies revealed the abundances of microbes in the rhizosphere correlated with the amount of exudate released by root cells, and it differed along with the roots (Mandic-Mulec et al. 2015). The tip of the oats root (Avena fatua L.) has the highest abundance of bacteria, followed by root hair and root base with the least population. The alteration of exudate patterns affects the microbes and greatly affects the microbial community structure and function. During chemotaxis, root exudate acts as an attractor or repellent of soil microbiota. As much as $10^{5}$ to $10^{7}$ bacteria for every gram of new root colonized the root surface. This condition was caused by plant-root exudate. Zhang et al. (2014) reported that citric acid found as the root exudates of cucumber plant and fumaric acid in banana root exudates affects the Bacillus subtilis N11 chemotaxis and biofilm formation. Based on the result presented in Figure 1, the result found in this study corresponds to the result reported by York et al. (2016), that exudates released by plants significantly affect the type and abundance of microorganisms.

The rhizosphere of $A$. pinnata showed the highest abundance of Bacillus. Arenga pinata generates

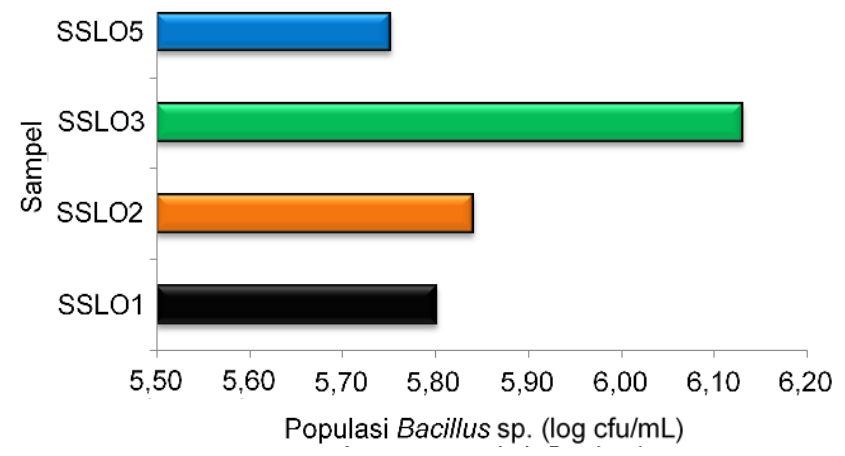

Figure 1 The abundance of Bacillus from rhizosphere soil in Mandalika island 
essential products called palm sugar. It makes the root exudate released is secure for the rhizosphere microbes. The compounds in palm fruit are essential for microbe growth, including carbohydrates, proteins, and lipids. It was completely different from the cacao plant $T$. cacao exudate. One of the active ingredients in the cacao pod is phenol, and it was effective as an antimicrobial agent (Sabbineni 2016). Hasanuddin et al. (2018) also reported the cacao rind contained a candidate of an antibacterial compound. Theobroma cacao was recognized as a major source of antioxidants. The three main polyphenol groups found in $T$. cacao are catechins or flavan-3-ols (37\%), proanthocyanidins $(58 \%)$, and anthocyanins $(4 \%)$ (Belščak et al. 2009). In the pharmaceutical, polyphenol showed an anti-carcinogenic, antiinflammatory, antimicrobial, and analgesic agents (Hii et al. 2009). This compound affected the abundance of Bacillus sp. in the cacao plant's rhizosphere. As another part of the cocoa plant, seeds have antibacterial and antioxidant activities, perhaps involving the microbial abundance in the rhizosphere soils (Hasanuddin et al. 2018). The bacterial abundance in the $P$. pterocarpum and $C$. nucifera were affected by root exudate. Li et al. (2019) and Sukumaran et al. (2011) reported that the plant bark and leaves of $P$. pterocarpum have antimicrobial, antivirus, antioxidant, antifungal, antivirus, and hepatoprotective activities. The root extract of $C$. nucifera, traditionally used as an antipyretic and diarrhea treatments (Lima et al. 2015). Those activities were estimated to influence the microbial abundance in the rhizosphere area.

The twenty-two isolates of selected members of the Bacillus were successfully collected from four different rhizosphere soil samples. Observation of Gram staining, spore staining, and morphological characteristics showed that isolates were Bacillus. These indicated by purple after Gram-staining (Grampositive), endospore formation, stem-shaped cells (Figure 2), catalase-positive, white-creamy color, irregular margins, and flat elevation.

The amplification results using a pair of universal primers for Eubacteria obtained an amplified area of $\sim 1.500$ bp. The 16S rRNA gene sequencing data

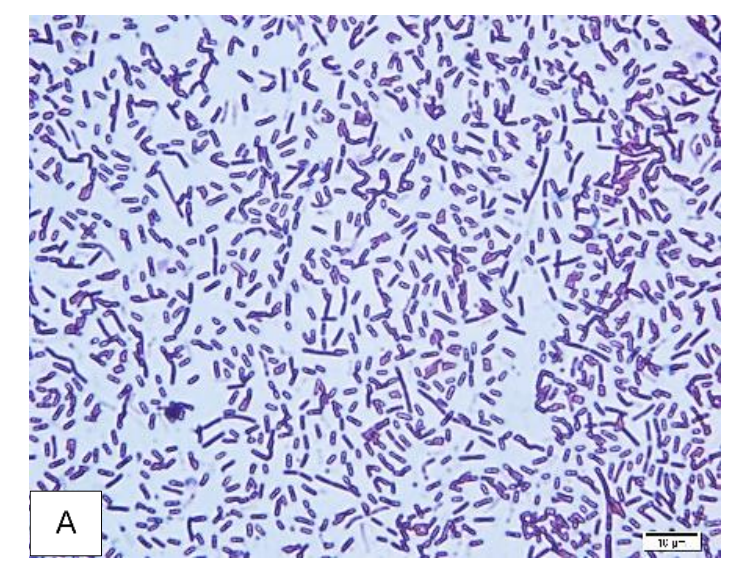

analysis revealed that the selected isolates were Bacillus. Among the twenty-two isolates represented thirteen species of Bacillus, one species of Fictibacillus, and one species of Brevibacillus, respectively. The abundance of Bacillus from each sample was not always proportional to the number of species collected. The code samples namely SSL01, SSL02, and SSL05, each was consisted of five species, whereas SSL03 only had one species (Table 1). Each sample contained different species of Bacillus, and it is supposed that exudates released by plant roots affecting the type of microbes found in the rhizosphere soils.

The isolation method used was selective for bacteria that able to form heat-resistant endospore at $80^{\circ} \mathrm{C}$. The data presented in Table 1 and Figure 3 revealed that isolated bacteria capable of creating endospores, included in the phylum Firmicutes, class Bacilli, and the Bacillales order. The collected isolates consisted of three genera, among others Bacillus, Brevibacillus, and Fictibacillus. Bacillus and Fictibacillus belong to the Bacillaceae, while Brevibacillus is a member of Paenibacillaceae (Figure 2). The composition of the selected isolate was Bacillus sp. (86,36\%), Brevibacillus sp. $(9,09 \%)$, and Fictibacillus sp. (4,54\%).

As well as Bacillus, Brevibacillus and Fictibacillus, taxonomically are Kingdom: Bacteria; Phylum: Firmicutes; Class: Bacilli; Order: Bacillales; Family: Bacillaceae (genus: Bacillus, Fictibacillus); Family: Paenibacillaceae (genus: Brevibacillus). They also form endospores and resistant to heat in isolation processes. The phenotypic characterization of the selected genus was Gram-positive, rod-shape, and cream-yellowish color. Based on the phenotypic characteristics, chemotaxonomy, genomic, and phylogenetic data, Shida et al. (1996) reclassified the bacteria like Bacillus become Brevibacillus, including Brevibacillus formosus, and Glaeser et al. (2013) proposed to reclassify $B$. solisalsi in the genus Fictibacillus.

Up to January 2021, Bacillus genera comprises 379 species, including synonym. To date, the molecular approach is the best strategy in bacterial grouping and identification. However, it has limitations, particularly for Bacillus classification. Phylogenetically, B. cucumis

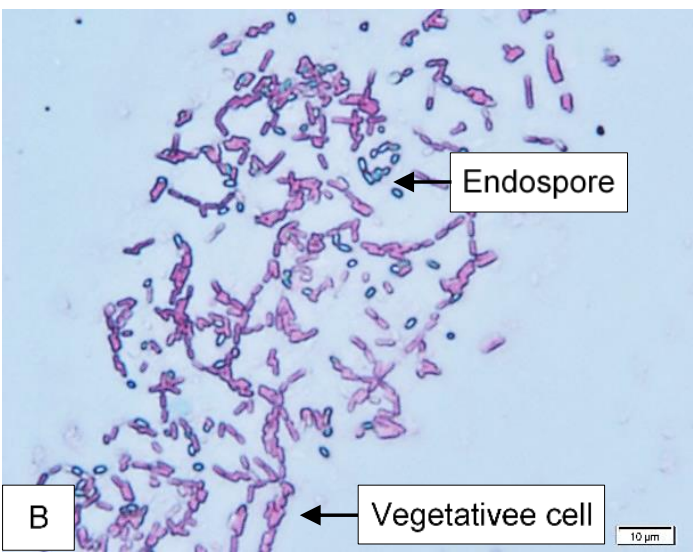

Figure 2 Gram staining (A) and spore staining (B) results of Bacillus sp. 
Table 1 Identification result of Bacillus basis on molecular approach of 16S rRNA gene sequence

\begin{tabular}{|c|c|c|c|c|}
\hline Isolate code & Top hit taxon & Basionym & Top hit strain & Similarity (\%) \\
\hline SSL01.1 & Bacillus wiedmannii & - & FSL W8-0169 & 99,59 \\
\hline SSL01.3 & Bacillus cucumis & - & AP-6 & 99,34 \\
\hline SSL01.4 & Bacillus cucumis & - & AP-6 & 99,42 \\
\hline SSL01.5 & Bacillus drentensis & - & LMG 21831 & 99,35 \\
\hline SSL01.6 & Bacillus pseudomycoides & - & DSM 12442(T) & 98,99 \\
\hline SSL01.7 & Bacillus pseudomycoides & - & DSM 12442(T) & 98,99 \\
\hline SSL01.8 & Bacillus acidiceler & - & CBD 119(T) & 99,81 \\
\hline SSL02.1 & Bacillus megaterium & - & NBRC 15308 & 100,00 \\
\hline SSL02.2 & Bacillus deserti & - & ZLD-8 & 99,70 \\
\hline SSL02.3 & Fictibacillus solisalsi & Bacillus solisalsi & YC1 & 99,86 \\
\hline SSL02.4 & Bacillus manliponensis & - & $\mathrm{BL} 4-6(\mathrm{~T})$ & 98,92 \\
\hline SSL02.5 & Bacillus megaterium & - & NBRC 15308 & 100,00 \\
\hline SSL02.7 & Bacillus aryabhattai & - & B8W22 & 100,00 \\
\hline SSL03.4 & Bacillus paramycoides & - & $\mathrm{NH} 24 \mathrm{~A} 2(\mathrm{~T})$ & 98,91 \\
\hline SSL05.1 & Bacillus cereus & - & ATCC 14579 & 100,00 \\
\hline SSL05.2 & Brevibacillus formosus & Bacillus formosus & DSM 9885 & 99,85 \\
\hline SSL05.3 & Brevibacillus formosus & Bacillus formosus & DSM 9885 & 99,78 \\
\hline SSL05.4 & Bacillus cytotoxicus & - & NVH 391-98(T) & 98,29 \\
\hline SSL05.5 & Bacillus ginsengisoli & - & DCY53 & 98,97 \\
\hline SSL05.6 & Bacillus acidiceler & - & CBD 119 & 99,93 \\
\hline SSL05.7 & Bacillus cytotoxicus & - & NVH 391-98(T) & 98,41 \\
\hline SSL05.8 & Bacillus acidiceler & - & CBD 119 & 99,93 \\
\hline
\end{tabular}

firmly connected with $B$. drentensis. It was distinguished from $B$. cucumis a century ago and recently confirmed as a different species. B. cucumis has some phenotypic and phylogenetic similarities. Other species are also very closed and hard to be separated utilizing the phylogenetic tree, as well $B$. acidiceler and B. luciferensis. B. brevis SSL05.2 and SSL05.3 showed 100 bootstrap values with other Brevibacillus groups. This case needs a particular technique to separate this species. As an alternative to $16 \mathrm{~S}$ rDNA sequence is protein-coding genes (e.g. $r p o B$, gyrB, nifD, recA, atpD) (Ki et al. 2009).

Bacillus is known as potential genera that able to produce commercially valuable enzymes. Each microbial strain has the ability to produce a large amount of hydrolysis and oxidation or reduction enzymes in its metabolic system. Even though they belong to the same species, the number and type of enzymes produced by each strain are not always same. This encourages the need to do microbial exploration that can produce specific enzymes in large quantities. The ability of bacteria in the enzyme production could be analyzed through a qualitative or quantitative approach. The qualitative approach aims to prove an enzyme existence in the sample. The data obtained are positive or negative based on the color change of the selective media used. This is the initial step in the screening process of biotechnology work. The quantitative approach determines enzyme activity in the sample and produces numerical data. The screening in the enzyme production showed that isolates of Bacillus were able to produce lipase, protease, and cellulase. The lipid crystals formed around the colony showed positive lipase. Protease and cellulase activities are marked by the formation of clear zones around the colony. The lipid crystals formed and color changes indicated activities of enzymes in hydrolyzing lipid polymers, proteins, and cellulose into simpler chemical compounds (Figure 4).

The results of the screening of enzyme-producing bacteria are presented in Table 2. Fourteen isolates of Bacillus and two isolates of Brevibacillus were able to produce hydrolysis enzymes lipase, protease, and cellulase. Ten isolates from 22 isolates had lipase activities, 13 isolates had protease activities, and two isolates had cellulase activities. Seven isolates were able to produce two types of enzymes i.e., lipase and protease. However, of the 22 isolates collected, none of them produced amylase and $\beta$-galactosidase enzymes.

Based on the activity, $B$. formosus signed as SSL05.2 and SSL05.3 were able to produce lipase, protease, and cellulase. Logan and Vos (2015) described that $B$. formosus able to hydrolyze casein and gelatin, but not for starch and urea. $B$. formosus BISR-1 collected from the Great Indian Desert soils can produce chitinase (Meena et al. 2014). B. formosus strains SSL05.2 and SSL05.3, and B. cucumis SSL01.3 had a high lipolytic index, and it revealed that those isolates could degrade lipid into fatty acids. $B$. acidiceler SSL01.8 and B. aryabhattai SSL02.7 had the highest proteolytic index. According to the data presented in Table 2, strains with lipase, cellulase, and protease activities are potentially used in biotechnological applications, such as detergent formulations or biodegradation of oil pollutants. Four classes of enzymes are generally used in the detergent formulation, including amylase, cellulase, lipase, and protease (Hasan et al. 2010). Six bacteria were $B$. deserti SSL02.2, F. solisalsi SSL02.3, B. gingsengisoli 
SSL05.5, B. acidiceler SSL05.6 and SSL05.8, and B. manliponensis SSL02.4 did not produce five types of enzymes tested.

\section{CONCLUSIONS}

The identification of Bacillus bacteria needs a more sensitive method besides 16S rRNA gene sequence. The protein-coding gene could be used as an alternative method to differentiate Bacillus. The abundances of microbes in the rhizosphere soils from Mandalika, Lombok Island are influenced by plant species and sampling locations. The root exudates released by plants significantly affect the type of microbes found in the rhizosphere soils. Bacillus genera isolated from Mandalika, Lombok Island, have the ability to produce hydrolytic enzymes cellulase,

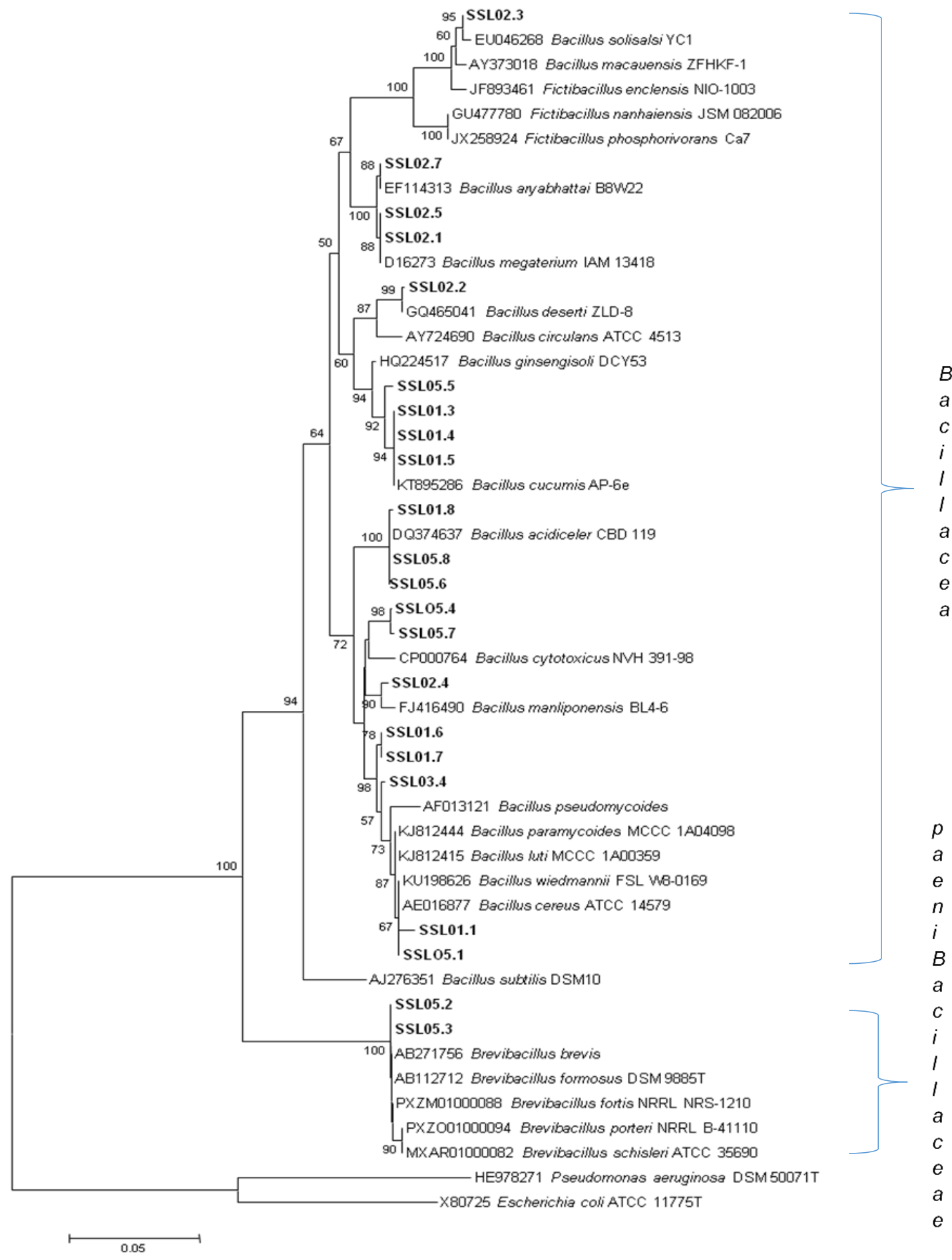

Figure 3 Phylogenetic tree of Bacillus isolates using Neighbor-Joining method and best model of Kimura 2-parameter and Gamma distributed with 1000 replications 

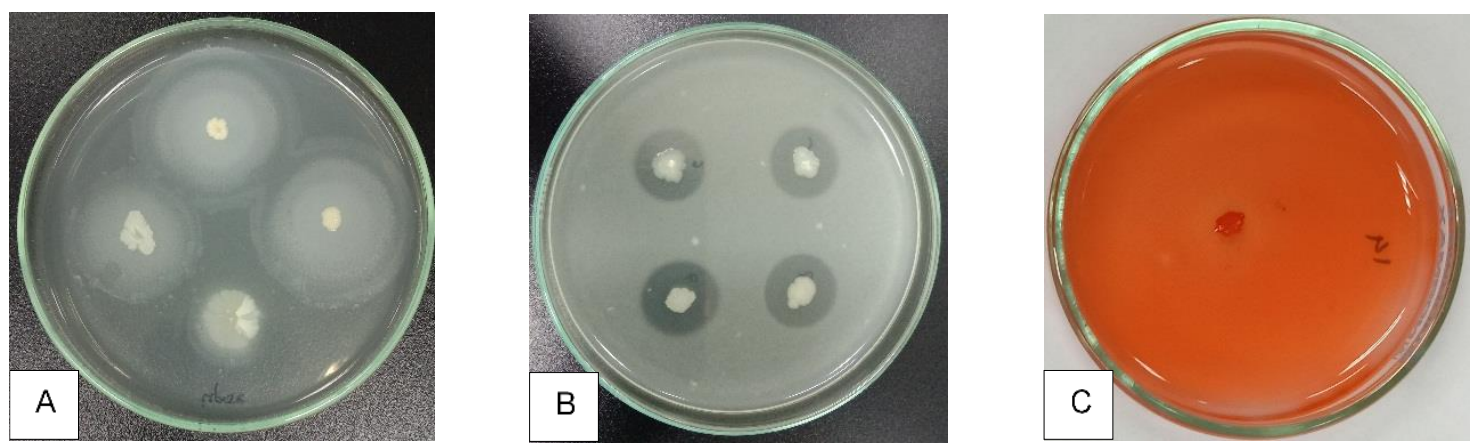

Figure 4 The screening result of enzyme activities of Bacillus isolates. (A: lipolytic activity; B: proteolytic activity, C: cellulolytic activity)

Table 2 The index of enzymes activity of Bacillus sp. collected from soil

\begin{tabular}{|c|c|c|c|c|c|}
\hline \multirow{2}{*}{ Isolate code } & \multicolumn{5}{|c|}{ Index } \\
\hline & Amylase & $\beta$-galactosidase & Cellulase & Lipase & Protease \\
\hline SSL01.1 & - & - & - & - & $1,13 \pm 0,18$ \\
\hline SSL01.3 & - & - & - & $3,25 \pm 0,18$ & - \\
\hline SSL01.4 & - & - & - & $2,57 \pm 0,20$ & - \\
\hline SSL01.5 & - & - & - & $0,97 \pm 0,17$ & - \\
\hline SSL01.6 & - & - & - & $0,95 \pm 0,06$ & $1,29 \pm 0,40$ \\
\hline SSL01.7 & - & - & - & $1,81 \pm 0,43$ & $1,19 \pm 0,09$ \\
\hline SSL01.8 & - & - & - & - & $1,57 \pm 0,20$ \\
\hline SSL02.1 & - & - & - & - & $1,31 \pm 0,09$ \\
\hline SSL02.2 & - & - & - & - & - \\
\hline SSL02.3 & - & - & - & - & - \\
\hline SSL02.5 & - & - & - & - & $1,25 \pm 0,00$ \\
\hline SSL03.4 & - & - & - & - & $1,13 \pm 0,18$ \\
\hline SSL05.1 & - & - & - & $0,32 \pm 0,14$ & $2,00 \pm 0,00$ \\
\hline SSL05.2 & - & - & $1,34 \pm 0,47$ & $5,20 \pm 0,28$ & $0,25 \pm 0,00$ \\
\hline SSL05.3 & - & - & $1,17 \pm 0,24$ & $5,40 \pm 0,28$ & $0,88 \pm 0,18$ \\
\hline SSL05.4 & - & - & - & $1,50 \pm 0,06$ & $0,88 \pm 0,18$ \\
\hline SSL05.5 & - & - & - & - & - \\
\hline SSL05.6 & - & - & - & - & - \\
\hline SSL05.7 & - & - & - & $1,85 \pm 0,07$ & $1,00 \pm 0,00$ \\
\hline SSL05.8 & - & - & - & - & - \\
\hline SSL02.4 & - & - & - & - & - \\
\hline SSL02.7 & - & - & - & - & $1,69 \pm 0,03$ \\
\hline
\end{tabular}

lipase, and protease. Those are potentially used in biotechnological applications as well in detergent formulations or biodegradation of oil pollutants.

\section{ACKNOWLEDGMENTS}

This research was supported by DIPA Project Research Center for Biology-Indonesian Institute of Sciences (LIPI)-2019. The best gratitude to Muhammad llyas and Indriati Ramadhani for the sample collection.

\section{REFERENCES}

Annamalai N, Rajeswari MV, Balasubramanian T. 2014. Extraction, purification and application of thermostable andhalostable alkaline protease from Bacillus alveayuensis CAS 5 using marine wastes. Food and Bioproducts Processing. 92(4): 335-342. https://doi.org/10.1016/j.fbp.2013.08.009
Belščak A, Komes D, Horžić D, Ganić KK, Karlović D. 2009. Comparative study of commercially available cocoa products in terms of their bioactive composition. Food Research International. 42(5-6): 707-716. https://doi.org/10.1016/j.foodres.200902 .018

Bulgarelli D, Garrido-Oter R, Münch PC, Weiman A, Dröge J, Pan Y, McHardy AC, Schulze-Lefert P. 2015. Structure and function of the bacterial root microbiota in wild and domesticated barley. Cell Host \& Microbe. 17: 392-403. https://doi.org/10.1 016/j.chom.2015.01.011

Castro RA, Quecine MC, Lacava PT, Batista BD, Luvizotto DM, Marcon J, Ferreira A, Melo IS, Azevedo JL. 2014. Isolation and enzyme bioprospection of endophytic bacteria associated with plants of Brazilian mangrove ecosystem. Springerplus. 3: 1-9. https://doi.org/10.1186/21-93 1801-3-382

Caulier S, Nannan C, Gillis A, Licciardi F, Bragard C, Mahillon J. 2019. Overview of the antimicrobial 
compounds produced by members of the Bacillus subtilis group. Frontiers in Microbiology. 10: 1-19. https://doi.org/10.3389/fmicb.2019.00302

Danilova I, Sharipova M. 2020. The Practical Potential of Bacilli and Their Enzymes for Industrial Production. Frontiers in Microbiology. 11: 1-782. https://doi.org/10.3389/fmicb.2020.01782

Glaeser SP, Dott W, Busse HJ, Kampfer P. 2013. Fictibacillus phosphorivorans gen. nov., sp. nov. and proposal to reclassify Bacillus arsenicus, Bacillus barbaricus, Bacillus macauensis, Bacillus nanhaiensis, Bacillus rigui, Bacillus solisalsi and Bacillus gelatini in the genus Fictibacillus. International Jounal of Systematic and Evolutionary Microbiology. 63: 2934-2944. https://doi.org/10.1 099/ijs.0.049171-0

Hasan F, Shah AA, Javed S, Hameed A. 2010. Enzymes used in detergents: Lipases, Review. African Journal of Biotechnolog. 9(31): 4836-4844.

Hasanuddin A, Anwar C, Mappatoba M, Husbandry A, Program S, Program DS, Program AS. 2018. Antibacterial and antioxidant activities of cocoa pod that associated in maltodextrin in various concentration. Agroland: The Agriculture Science Journal. 5(2): 123-131. https://doi.org/10.22487/j 24077593.2018.v5.i2.12188

Hii C, Law C, Suzannah S, Cloke M. 2009. Polyphenols in cocoa (Theobroma cacao L.). Asian Journal Food and Agro-Indusrtry. 2(4): 702-722. https://doi.org/ 10.1590/S1517-83822000000400-003

Ki JS, Zhang W, Qian PY. 2009. Discovery of marine Bacillus species by $16 \mathrm{~S}$ rRNA and rpoB comparisons and their usefulness for species identification. Journal of Microbiology Methods 77(1): 48-57. https://doi.org/10.1016/j.mimet.200 9.01 .003

Lane D. 1991. 16S/23S rRNA sequencing. In: Nucleic Acid Techniques In Bacterial Systematics. New York(US): John Wiley and Sons. pp 115-175.

Li YC, Kuo PC, Yang ML, Chen TY, Hwang TL, Chiang CC, Thang TD, Tuan NN, Tzen JTC. 2019. Chemical constituents of the leaves of Peltophorum pterocarpum and their bioactivity. Molecules. 24: 1-11. https://doi.org/10.3390/molecules240202-40

Lima EBC, Sousa CNS, Meneses LN, Ximenes NC, Santos Júnior MA, Vasconcelos GS, Lima NBC, Patrocinio MCA, Macedo D, Vasconcelos SMM. 2015. Cocos nucifera (L.) (Arecaceae): A phytochemical and pharmacological review. Brazilian Journal of Medical and Biological Research. 48(11): 953-964. https://doi.org/10.1590 /1414-431x201547733

Logan NA, Vos P De. 2015. Brevibacillus. Bergey's Manual of Systematics of Archaea and Bacteria.
1-22. https://doi.org/10.1002/9781118960608.gbm 00550

Mandic-Mulec I, Stefanic P, van Elsas JD. 2015. Ecology of Bacillaceae. Microbiology Spectrum. 3(2): 1-24. https://doi.org/10.1128/microbiolspec .TBS-0017-2013

Mazzucotelli CA, Ponce AG, Kotlar CE, Moreira M del R. 2013. Isolation and characterization of bacterial strains with a hydrolytic profile with potential use in bioconversion of agroindustial by-products and waste. Food Science and Technology. 33(2): 295-303. https://doi.org/10.1590/S0101-20612013 005000038

Meena S, Gothwal RK, Krishna Mohan M, Ghosh P. 2014. Production and purification of a hyperthermostable chitinase from Brevibacillus formosus BISR-1 isolated from the Great Indian Desert soils. Extremophiles. 18: 451-462. https:// doi.org/10.1007/s00792-014-0630-4

Packeiser H, Lim C, Balagurunathan B, Wu J, Zhao H. 2013. An extremely simple and effective colony PCR procedure for bacteria, yeasts, and microalgae. Applied Biochemistry and Biotechnology. 169: 695-700. https://doi.org/10.1 007/s12010-012-0043-8

Parte AC, Road W. 2014. LPSN-list of prokaryotic names with standing in nomenclature. Nucleic Acids Research. 42: 613-616. https://doi.org/10.1093/n ar/gkt1111

Pereyra M, Giacomo AL Di, Lara AL, Martínez MP, Cavaglieri L. 2020. Aflatoxin-degrading Bacillus sp . strains degrade zearalenone and produce proteases, amylases and cellulases of agroindustrial interest. Toxicon. 180: 43-48. https://doi .org/10.1016/j.toxicon.2020.04.006

Powthong P, Suntornthiticharoen P. 2017. Antimicrobial and enzyme activity produced by Bacillus spp. isolated from soil. International Journal of Pharmacy and Pharmaceutical Sciences. 9(3): 205-210. https://doi.org/10.22159/ijpps.2017v9i3.1 3895

Sabbineni J. 2016. Phenol-an effective antibacterial agent. Journal Medicinal \& Organic Chemistry. 3(2): 182-191.

Schlaeppi K, Dombrowski N, Oter RG, Ver Loren Van Themaat E, Schulze-Lefert P. 2014. Quantitative divergence of the bacterial root microbiota in Arabidopsis thaliana relatives. Proceeding of The National Academy of Science. 111(2): 585-592. https://doi.org/10.1073/pnas.1321597111

Schultz M, Burton JP, Chanyi RM. 2017. Use of Bacillus in Human Intestinal Probiotic Applications. Amsterdam (NL): Elsevier Inc. https://doi.org/10.10 16/B978-0-12-804024-9.00011-2 
Shanthi V, Roymon MG. 2018. Isolation, identification and partial optimization of novel xylanolytic bacterial isolates from Bhilai-Durg region, Chhattisgarh, India. Iran Journal Biotechnology. 16(3): 200-212. https://doi.org/10.21859/ijb.1333

Shida O, Takagi H, Kadowaki K, Komagata K. 1996. Proposal for Two New Genera, Brevibacillus gen. nov. and Aneurinibacillus gen. nov. International Journal of Systematic and Evolutionary Microbiology. 46(4): 939-946. https://doi.org/10.1 099/00207713-46-4-939

Shrestha A, Sultana R, Chae JC, Kim K, Lee KJ. 2015. Bacillus thuringiensis $\mathrm{C} 25$ which is rich in cell wall degrading enzymes efficiently controls lettuce drop caused by Sclerotinia minor. European Journal of Plant Pathology. 142: 577-589. https://doi.org/10.1 007/s10658-015-0636-5

Sukumaran S, Kiruba S, Mahesh M, Nisha SR, Miller PZ, Ben CP, Jeeva S. 2011. Phytochemical constituents and antibacterial efficacy of the flowers of Peltophorum pterocarpum (DC.) Baker ex Heyne. Asian Pacific Journal of Tropical Medicine. 4(9): 735-738. https://doi.org/10.1016/S1995-7645(11)6 0183-1

Tamura K, Stecher G, Peterson D, Filipski A, Kumar S. 2013. MEGA6: Molecular evolutionary genetics analysis version 6.0. Moecularl Biology and
Evolution. 30: 2725-2729. https://doi.org/10.1093/ molbev/mst197

van Dijl JM and Hecker M. 2013. Bacillus subtilis: from soil bacterium to super secreting cell factory. Microbial Cell Factories. 12(3): 1-6. https://doi.org /10.1186/1475-2859-12-3

Yoon S, Ha S, Kwon S, Lim J, Kim Y, Seo H, Chun J. 2017. Introducing EzBioCloud: a taxonomically united database of $16 \mathrm{~S}$ rRNA gene sequences and whole-genome assemblies. International Journal of Systematic and Evolutionary Microbiology. 67(5): 1613-1617. https://doi.org/10.1099/ijsem.0.0017 55

York LM, Carminati A, Mooney SJ, Ritz K, Bennett MJ. 2016. The holistic rhizosphere: integrating zones, processes, and semantics in the soil influenced by roots. Journal of Experimental Botany. 67(12): 3629-3643. https://doi.org/10.1093/jxb/erw108

Zhang N, Wang D, Liu Y, Li S, Shen Q, Zhang R. 2014. Effects of different plant root exudates and their organic acid components on chemotaxis, biofilm formation and colonization by beneficial rhizosphere -associated bacterial strains. Plant and Soil. 374: 689-700. https://doi.org/10.1007/s111 04-013191 5-6 